\title{
THE INFLUENCE OF NUTRITION ON MUSCLE WASTING IN CRITICALLY ILL PATIENTS - A PILOT STUDY
}

\author{
Andonovska Biljana, Andonovski Alan, Kuzmanovska Biljana, \\ Kartalov Adrijan, Temelkovski Zlatko \\ University Clinic of Traumatology, Orthopedic Surgery, Anesthesiology, \\ Intensive Care and Emergency Center - Intensive Care Unit - Skopje, Macedonia
}

Primljen/Received 21. 08. 2018. god.

Abstract: Introduction: Adequate nutrition is necessary to prevent muscle wasting in critically ill patients. Decision about enteral or parenteral nutrition is always questionable. Objective: The aim of our study was to assess the impact of nutrition on muscle wasting in critically ill patients with trauma injury. Material and methods: The study was conducted in the period from January to December 2017 and included 30 critically ill patients with trauma injury hospitalized on the Intensive care unit (ICU) of the University clinic for anesthesiology and intensive care in Skopje. Included patients were divided into two groups: group $\mathbf{E}$ - patients where enteral nutrition was conducted after the third day of their admission in ICU and group $\mathbf{P}$ - patients where total parenteral nutrition was implemented in the first 24 hours of their admission.

The study monitored the impact of two different types of nutrition on muscle wasting evaluated by ultrasound measurements of m.quadriceps femoris thickness and biochemical measurements of the serum creatinine level. Results: In group E there was statistically significant muscle wasting evaluated by ultrasound between the $1^{\text {st }}$ and the $3^{\text {rd }}$ and the $1^{\text {st }}$ and the $7^{\text {th }}$ day. Difference in measured muscle thickness was $1.90 \pm 1.49 \mathrm{~mm}$ between the $1^{\text {st }}$ and the $3^{\text {rd }}(\mathrm{p}=0.015)$ and $4.46 \pm 2.81 \mathrm{~mm}$ between the $1^{\text {st }}$ and the $7^{\text {th }}$ day $(\mathrm{p}=0.006)$. In group P muscle wasting in the same period was without statistical significance. Both groups showed statistically significant decrease in serum creatinine levels between the $1^{\text {st }}$ and the $3^{\text {rd }}(\mathrm{p}=0.003, \mathrm{p}=0.03)$ and the $1^{\text {st }}$ and $7^{\text {th }}(\mathrm{p}=$ $0.003)$ day. The values of differences between the $1^{\text {st }}$ and the $3^{\text {rd }}$ and the $1^{\text {st }}$ and the $7^{\text {th }}$ day were $7.57 \pm 4.12 \mathrm{mg} / \mathrm{dl}$ and $10.71 \pm 5.79 \mathrm{mg} / \mathrm{dl}$ in group $\mathrm{E}$ and $11.43 \pm 10.66$ $\mathrm{mg} / \mathrm{dl}$ and $15.28 \pm 8.28 \mathrm{mg} / \mathrm{dl}$ in group P.

Conclusion: In our study we determined a significant decrease of muscle mass evaluated by ultrasound
Prihvaćen/Accepted 01. 11. 2018. god.

measurements of m.quadriceps femoris thickness in patients with enteral nutrition after the third day.

Key words: Critically ill patients, Enteral or parenteral nutrition, Muscle wasting, Ultrasonography, Serum creatinine concentration.

\section{INTRODUCTION}

In critically ill patients there is often muscle mass wasting and impaired muscle function. This leads to prolonged treatment, delayed rehabilitation, and reduced quality of life even up to five years after the acute suffering $(1,2)$. Muscle wasting as a complex problem beside from malnutrition it can be is also caused by immobilization, inflammation, and hyperglycemia. In order to prevent muscle-protein depletion and to provide nitrogen balance over the years, numerous strategies have been proposed. One of these strategies is adequate nutrition, which plays an important role in the general therapy of critically ill patients. Enteral nutrition has been always the primary alternative for nutrition in critically ill patients, and it is a superior nutritional type. The importance of the intestines as a part of the systemic response to injury and trauma is well known $(3,4)$. The non-use of the gastrointestinal tract leads to changes in intestinal microflora, impaired mucosal and immunological barrier leading to septic complications and organic failure (5). Unfortunately even in patients without contraindications for enteral nutrition, efforts to ensure proper nutrition through this pathway in the early stages of the disease are often hampered by the symptoms of gastrointestinal intolerance. In that case, the next option is parenteral nutrition. The parenteral nutrition is often called hyperalimentation, although it does not provide excessive caloric value. However, the parenteral nutrition sometimes is associated with seve- 
ral complications and harmful effects on the immune system to the extent that it is often called a "total poisonous diet". The recent studies and obtained data do not agree with previously mentioned conclusions $(6,7)$.

Despite the advances in nutritional therapy, its main goal to prevent further protein loss often cannot be achieved. Patients in intensive care units (ICU) are continuously nourished and they do not starve, but catabolism and muscle reduction continues for a longer period of time. The muscle wasting in patients can be masked by the excess fat in sarcopenic obesity or fluid retention that can account for 10 to $20 \%$ of the body weight of critically ill patients $(8,9)$.

There are several methods for assessing muscle mass and muscle wasting. Ultrasonography is a new non-invasive technique that allows identification of changes in the muscular structure and morphology (10). Campbell et al. showed that ultrasonography allows identification and quantification of muscle wasting in edematous patients with multiple organic weaknesses (11). Also, the measures obtained by ultrasonography correlate with the measures obtained with CT diagnostics (12).

Creatinine is an endogenous substance with muscle origin generated by non-enzyme conversion of creatine and creatine phosphate (13). It is filtered through the kidneys without tubular reabsorption. So, the serum creatinine concentration is used to estimate glomerular filtration and renal function. It is also a powerful predictive indicator for mortality and outcome for hospital patients (14). As a consequence of the confirmed correlation between the serum creatinine and muscle mass, the serum creatinine concentration is used as a surrogate measure of muscle mass wasting (15).

The aim of the study was to assess the impact of two different types of nutrition on muscle wasting primary evaluated with ultrasound measurements of of $m$. quadriceps femoris muscle thickness and secondary evaluated by serum creatinine level determination in critically ill patients with trauma injury.

\section{MATERIAL AND METHODS}

The study was conducted in the period from January to December 2017., and included 30 critically ill patients with trauma injury hospitalized on the ICU of the University clinic for anesthesiology and intensive care. The included patients had mean age of 34 years ( range from 16 to 50 years) and were equally divided into two groups: group $\mathbf{E}$ - with 15 patients where enteral nutrition was conducted after the third day of their admission and group $\mathbf{P}$-with 15 patients where total parenteral nutrition was implemented in the first 24 hours of their admission. The aim of both types of nutrition was to obtain energy requirements with $20-25 \mathrm{kal} / \mathrm{kg} /$ day for each patient.
The study included patients older than 18 years of age where there was a need for intubation and mechanical ventilation, the need for treatment in ICU for more than seven days, patients with relative contraindications for enteral nutrition and indication for hospitalization due to polytrauma graded with medium to heavy Injury severity scores (ISS) (16). The study excluded the patients who did not meet the before mentioned criteria, pregnant women, patients with lower limb amputation and those with primary neuromuscular disease, disseminated carcinoma, renal disease, acute shock with systolic blood pressure less than $90 \mathrm{~mm} \mathrm{Hg}$ or median arterial pressure below $70 \mathrm{mmHg}$, nutritional allergy, and absolute contraindication for enteral nutrition.

Absolute contraindication for enteral nutrition was:

- Massive intestines resection, with or without colon resection

- Proximal fistula with high output

- Perforation of the small intestines

The study evaluated the effect of two types of nutrition on patients muscle wasting which was measured by ultrasonography on the $1^{\text {st }}, 3^{\text {rd }}$, and $7^{\text {th }}$ day of their admission in ICU. The measurements were carried out by a single operator with a portable ultrasonograph $\mathrm{Si}$ emens Acuson X 300 and transducer VF13-5 (Figure 1). To determine muscle wasting, the thickness of $\mathrm{m}$. quadriceps femoris ( $\mathrm{m}$. vastus intermedius and $\mathrm{m}$. rectus femoris) - was measured at a two precisely determined points: the point between the lower third and the upper two-thirds of $\mathrm{m}$. quadriceps femoris and the median point between the spina illiaca anterior superior and the upper pole of the patella, with the patientin the supinated position and the leg relaxed in extension (Figure 2).The mean value of the measurements at both points was calculated finally.

Biochemical analysis of serum creatinine concentration was performed on the $1^{\text {st }}, 3^{\text {rd }}$, and $7^{\text {th }}$ day of the admission in ICU.

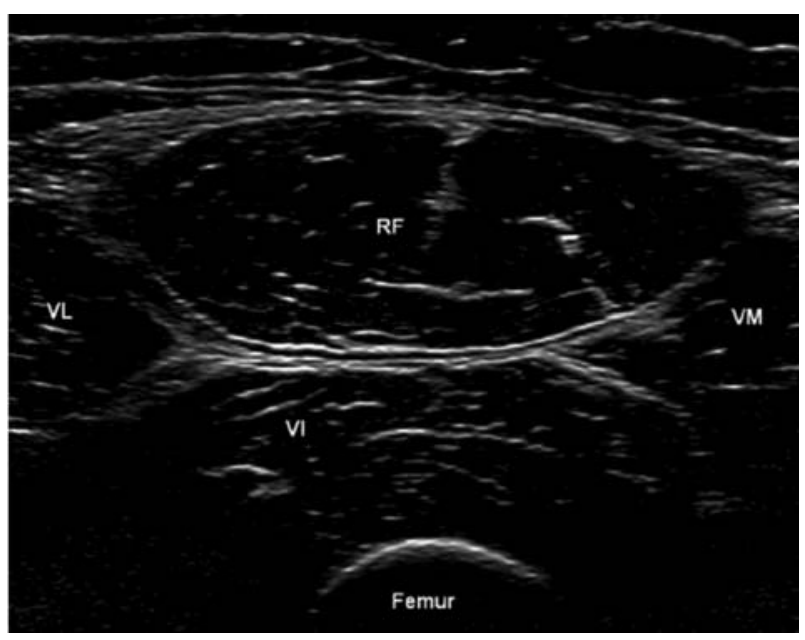

Figure 1. Ultrasound image of m. quadriceps femoris 


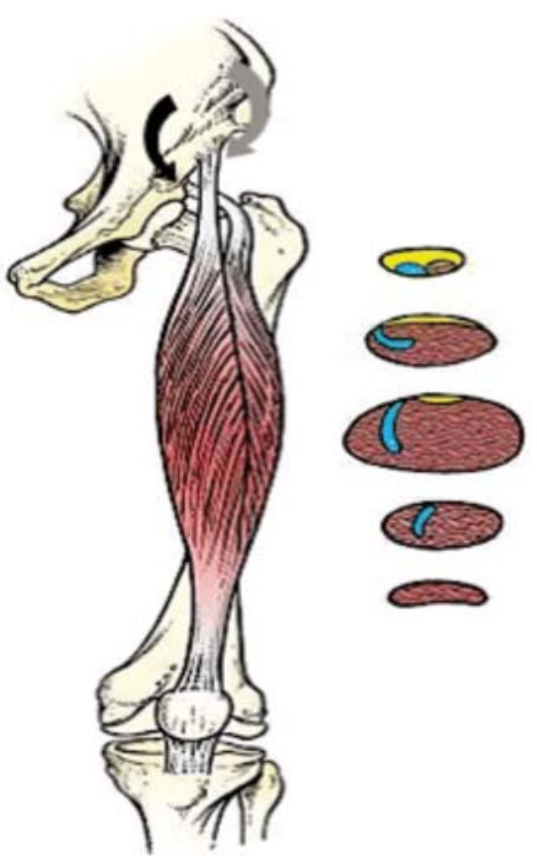

Figure 2. Picture with anatomic presentation of $m$. vastus intermedius and $m$. rectus femoris

Randomization was performed with closed envelopes, with number 1 for E group and number 2 for $\mathrm{P}$ group. The relatives of the patients were familiar with this research and they voluntarily signed a document for informational consent and took part in randomization. The research was prospective and randomized.

\section{Statistical analysis}

All data were presented as a mean value \pm standard deviation and analyzed with SPSS 12.0 software. The comparison between the groups was made with $t$ test and the difference of $p<0.05$ was considered statistically significant.

\section{RESULTS}

\section{Ultrasound analysis}

Analysis between the $1^{\text {st }}$ and the $3^{\text {rd }}$, the $1^{\text {st }}$ and the $7^{\text {th }}$, as well as the $3^{\text {rd }}$ and the $7^{\text {th }}$ day (Table 1) showed that in group $\mathrm{E}$ with enteral nutrition there is a statistically significant decrease in muscle mass between the $1^{\text {st }}$ and the $3^{\text {rd }}$ day $(\mathrm{p}=0.015)$ and between the $1^{\text {st }}$ and the $7^{\text {th }}$ day $(\mathrm{p}=$ 0.006 ). The difference between the $3^{\text {rd }}$ and the $7^{\text {th }}$ day was near the border of statistical significance $(p=0.065)$.

Analysis between the $1^{\text {st }}$ and the $3^{\text {rd }}$, the $1^{\text {st }}$ and the $7^{\text {th }}$, as well as the $3^{\text {rd }}$ and the $7^{\text {th }}$ day in the group P with early parenteral nutrition in all cases showed a decreased muscle mass but without statistical significance (Table 2). The greatest reduction in muscle mass was seen between the $1^{\text {st }}$ and the $7^{\text {th }}$ day $(p=0.070)$.

\section{Serum creatinine analysis}

Analysis of serum creatinine level measured in group E showed that there is a decreasing in the measu-

Table 1. Differences in muscle mass loss $(\mathrm{mm})$ at different time intervals in group E with enteral nutrition measured by ultrasonography

\begin{tabular}{|c|c|c|c|}
\hline \multirow{2}{*}{$\begin{array}{c}\text { Time intervals for } \\
\text { Ultrasound measurements }\end{array}$} & \multicolumn{3}{|c|}{ Differences in Ultrasound measured muscle thickness } \\
& \multicolumn{3}{c|}{ (mm) } \\
\cline { 2 - 4 } & MV \pm SD & Min - Max & p value \\
\hline 1-3 day & $1,90 \pm 1,49$ & $0,51-3,29$ & 0,015 \\
\hline 1-7 day & $4,46 \pm 2,81$ & $1,86-7,06$ & 0,006 \\
\hline 3-7 day & $2,56 \pm 3,00$ & $0,22-5,34$ & 0,065 \\
\hline
\end{tabular}

Table 2. Differences in muscle mass loss $(\mathrm{mm})$ at different time intervals in group $P$ with early parenteral nutrition measured by ultrasonography

\begin{tabular}{|c|c|c|c|}
\hline \multirow{2}{*}{$\begin{array}{c}\text { Time intervals for } \\
\text { Ultrasound measurements }\end{array}$} & \multicolumn{3}{|c|}{ Differences in Ultrasound measured muscle thickness } \\
\cline { 2 - 4 } & MV \pm SD & Min - Max & p value \\
\hline $1-3$ day & $1,81 \pm 3,25$ & $1,19-4,82$ & 0,190 \\
\hline $1-7$ day & $2,44 \pm 2,94$ & $0,27-5,16$ & 0,070 \\
\hline $3-7$ day & $0,63 \pm 2,67$ & $1,84-3,09$ & 0,556 \\
\hline
\end{tabular}

Table 3. Differences in serum creatinine concentration $(\mathrm{mg} / \mathrm{dl})$ at different time intervals in Group E with enteral nutrition

\begin{tabular}{|c|c|c|c|}
\hline \multirow{2}{*}{$\begin{array}{c}\text { Time intervals for serum } \\
\text { creatinine measurements }\end{array}$} & \multicolumn{3}{|c|}{ Differences in serum creatinine measurements } \\
\cline { 2 - 4 } & $\mathrm{mg} / \mathrm{dl})$ & $\mathrm{p}$ value \\
\hline $1-3$ day & $7,57 \pm 4,12$ & Min - Max & 0,003 \\
\hline 1-7 day & $10,71 \pm 5,79$ & $3,76-11,38$ & 0,003 \\
\hline 3-7 day & $3,14 \pm 5,30$ & $5,35-16,07$ & 0,168 \\
\hline
\end{tabular}


Table 4. Differences in serum creatinine concentration ( $\mathrm{mg} / \mathrm{dl}$ ) at different time intervals in group $P$ with early parenteral nutrition

\begin{tabular}{|c|c|c|c|}
\hline \multirow{2}{*}{$\begin{array}{c}\text { Time intervals for serum } \\
\text { creatinine measurements }\end{array}$} & \multicolumn{3}{|c|}{ Differences in serum creatinine measurements } \\
\cline { 2 - 4 } & $\mathrm{MV} \pm \mathrm{SD}$ & Min - Max & $\mathrm{p}$ value \\
\hline 1-3 day & $11,43 \pm 10,66$ & $1,57-21,29$ & 0,030 \\
\hline 1-7 day & $15,28 \pm 8,28$ & $7,63-22,94$ & 0,003 \\
\hline 3-7 day & $3,86 \pm 6,59$ & $2,24-9,95$ & 0,173 \\
\hline
\end{tabular}

red values of serum creatinine concentration with statistical significant difference between the $1^{\text {st }}$ andthe $3^{\text {rd }}(\mathrm{p}$ $=0.003)$ andthe $1^{\text {st }}$ and the $7^{\text {th }}(\mathrm{p}=0.003)$ day (Table 3$)$.

The analysis of serum creatinine level measured in group P showed that there is a decreasing in the measured values of serum creatinine concentration with statistical significant difference between the $1^{\text {st }}$ and the $3^{\text {rd }}(\mathrm{p}$ $=0.03)$ and the $1^{\text {st }}$ and the $7^{\text {th }}(\mathrm{p}=0.003)$ day $($ Table 4$)$.

\section{DISCUSSION}

In healthy persons, skeletal muscles are maintained as a balance between protein synthesis and protein digestion. Any prolonged change in balance will result in increased or decreased muscle mass (17).

Negative nitrogen balance and loss of muscle mass in correlation with trauma was described for the first time in 1932. Trauma is a cascade of inflammatory, immune, endocrine, and metabolic changes and it causes catabolism characterized by loss of body weight, muscle mass and strength reduction, as a consequence of the dominant proteolysis in terms of protein synthesis. Critically ill patients in the catabolic phase excreted 15 grams of nitrogen in urine versus normal losses of 0.7 to 1.4 grams per day, which is 94 grams of muscle protein or daily loss of $0.47 \mathrm{~kg}$ muscle mass. It's extremely severe muscle reduction (18). That is why critically ill patients need nutrients either in the form of enteral or parenteral nutrition, in order to avoid the energy deficiency which can lead to protein utilization and muscle tissue wasting (19). It is estimated that most patients in intensive care units receive only $49 \%$ to $70 \%$ of estimated caloric needs $(20,21)$. Although there is general agreement that excessive hypo-caloric or hyper-caloric nutrition should be avoided, there is still no consensus on how much the daily needs should be (22). Except the right caloric intake nutrition must also obtain the right protein intake in order to prevent muscle mass wasting $(23,24,25,26)$. Although there are some investigations, the pathophysiology of muscle wasting and the influence of nutrition on muscle wasting is still not well known. Different studies present different results according to this pathology.

Puthucheary et al. (27) showed that the catabolic condition and rapid muscle wasting in the first week of the critical illness may be independent of enteral nutrition. Using ultrasonography they determined $17 \%$ muscle mass wasting of rectus femoris muscle in the first 7 days of hospitalization. Contrary to expectations, in their study, high delivery of proteins through a nasogastric probe in the first week of a critical illness was associated with greater muscle wasting, thus challenging the idea that the beginning of enteral nutrition is beneficial. The criteria and timing of parenteral nutrition are also debatable. The study from Ferrie et al. (28) showed that the patients who took parenteral nutrition with $1.2 \mathrm{~g} / \mathrm{kg} /$ day proteins had less muscle wasting of rectus femoris muscle than those who took $0.8 \mathrm{~g} / \mathrm{kg} / \mathrm{day}$. Opposite to this study the EPaNIC study did not find any benefit of early parenteral nutrition on muscle wasting in the first days of hospitalization. According to the study from Casaer et al. (29) the early parenteral nutrition is associated with inhibited autophagy and impaired muscle integrity. Tolerating the macronutrient deficiency in the first week reduces the risk of muscle wasting. Hermans et al.considering the EPANIC study, concluded that the muscle wasting in patients with late parenteral nutrition group is slightly lower than in patients with early parenteral nutrition (30). Opposite to him Doig et al. (31) found lower muscle wasting in the early parenteral nutrition group. In another large multicentre study in patients with relative contraindication for enteral nutrition, the early application of parenteral nutrition reduced the duration of mechanical ventilation and potentially reduced the risk of muscle wasting $(32,33)$.

In our study, it was found that in Group E with patients who received enteral nutrition after the third day, there was a progressive muscle mass wasting with a statistical significance between the first and the third ( $p$ $=0.015)$ and the first and the seventh $(p=0.006)$ day. In group P patients who began to receive parenteral nutrition in the first 24 hours, did not show significant muscle mass wasting. Our results correlate with the results of the Doig et al. who reported lower muscle wasting in the group with early parenteral nutrition versus the group with standard nutrition (31). In our study to determine muscle wasting, the thickness of $\mathrm{m}$. quadriceps femoris ( $\mathrm{m}$. vastus intermedius and $\mathrm{m}$. rectus femoris) was measured by ultrasonography. Measure- 
ment of muscle wasting by ultrasonography in patients in intensive care units is selected as a very practical one and at the same time the only possible solution compared to other techniques such as computed tomography, magnetic resonance, densitometry and others $(34,35$, $36,37)$. So far, different muscle measurements have been described to determine muscle mass wasting (38, $39,40,41)$. As in other studies, m. quadriceps femoris was used in our evaluation study as a muscle that is well described and easily visualized in conditions of impaired muscular architecture $(36,37)$.

To determine muscle wasting we also measured the concentration of serum creatinine. The leading cause of low serum creatinine concentration is low muscle mass (Table 5). The correlation between muscle mass and serum creatinine in one of the studies is $\mathrm{r}=0.734$ [95\% CI 0.656 to 0.797 ] and $\mathrm{r}=0.706$ [95\% CI 0.620; $0.774]$; with a significance $(p=0.0001)$. In other words, malnourished people with lower muscle mass have lower levels of serum creatinine (42). In our study, the values of serum creatinine in group E significantly decreased between the first and third day and between the first and the seventh day $p=0.003$. The same decrease in serum creatinine values occurred in the group $P$ with statistical significance of $(p=0.03)$ between the first and the third day, and between the first and the seventh day $(\mathrm{p}=0.003)$.

\section{CONCLUSION}

From a brief review through the literature, it can be concluded that controversies about providing optimum energy, form of nutrition, and timing of initiation exist continuously, especially in the early phase of the critical illness. The nutritional strategy and goal should be personalized for individual patients. Muscles wasting measured with ultrasonography and serum creatinine analysis, are indicators of malnutrition, but also conditions subjected to other influences. In our pilot
Table 5. Factors affecting low serum creatinine levels

\begin{tabular}{|c|}
\hline Small muscle mass \\
\hline Malnutrition \\
\hline Hepatic lesion \\
\hline Water shift \\
\hline Increased renal clearance \\
\hline
\end{tabular}

study, we determined a significant reduction in muscle mass in patients with relative contraindication of enteral nutrition and beginning of enteral nutrition after the third day, versus patients with early beginning of parenteral nutrition where we came to the conclusion that there is a decrease in muscle mass, but without statistical significance. Regarding the values of serum creatinine in both groups, there was a significant decrease in values in the both groups. The series of patients included in the study was small, and the reliability of the results required an extension of the study.

\section{DECLARATION OF INTEREST}

The authors declare that there are no conflicts of interest.

\section{Ethical approval}

This study is the part of a doctoral study. The local institutional review board approved this study.
Abbreviations
ICU - Intensive care units
CT - Computer tomography
ISS - Injury Severity Score

\section{Licensing}

This work is licensed under a Creative Commons Attribution 4.0 International (CC BY 4.0) License.

\title{
Sažetak
}

\section{UTICAJ ISHRANE NA GUBITAK MIŠIĆA KOD KRITIČNO OBOLELIH PACIJENATA - PILOT STUDIJA}

\author{
Andonovska Biljana, Andonovski Alan, Kuzmanovska Biljana, Kartalov Adrijan, Temelkovski Zlatko \\ University Clinic of Traumatology, Orthopedic Surgery, Anesthesiology, \\ Intensive Care and Emergency Center - Intensive Care Unit - Skopje, Macedonia
}

Uvod: Adekvatna ishrana je neophodna kako bi se sprečio gubitak mišića kod kritično obolelih pacijenata. Odluka o enteralnoj ili parenteralnoj ishrani uvek je dovedena u pitanje.

Cilj: Cilj naše studije bio je utvrditi uticaj ishrane na gubitak mišića kod kritično obolelih pacijenata sa traumatskim povredama. Materijali i metode: Istraživanje je sprovedeno od januara do decembra 2017. godine i uključilo je 30 kritično obolelih pacijenata sa traumatskim povredama, hospitalizovanih u jedinici intenzivne nege (JIN) na Univerzitetskoj klinici za anesteziologiju i intenzivnu negu u Skoplju. Pacijenti, koji 
su bili uključeni u studiju, bili su podeljeni u dve grupe: grupu E - sa pacijentima kod kojih je enteralna ishrana sprovedena trećeg dana nakon njihovog prijema u JIN i grupu P - sa pacijentima kod kojih je kompletna parenteralna ishrana sprovedena u prva 24 sata od prijema u JIN.

Studija je pratila uticaj dva različita tipa ishrane na gubitak mišićne mase evaluirane ultrazvučnim merenjem debljine m. quadriceps femorisa i biohemijskim merenjem nivoa kreatinina u serumu. Rezultati: U grupi E je postojao statistički značajan gubitak mišićne mase procenjen ultrazvukom između 1. i 3. i 1. i 7. dana. Razlika u debljini mišića iznosila je 1,90 \pm $1,49 \mathrm{~mm}$ između 1. i 3 . $(\mathrm{p}=0,015)$ i 4,46 $\pm 2,81 \mathrm{~mm}$ iz-

\section{REFERENCES}

1. Herridge MS, Tansey CM, Matté A, Tomlinson G, Diaz-Granados N, Cooper A et al. Functional disability 5 years after acute respiratory distress syndrome. $\mathrm{N}$ engl J Med. 2011; 364(14): 1293-304.

2. Iwashyna TJ, Ely EW, Smith DM, Langa KM. Long-term cognitive impairment and functional disability among survivors of severe sepsis. JAMA. 2010; 304(16): 1787-94.

3. Souba WW, Klimberg VS, Plumley DA, Salloum RM, Flynn TC, Bland KI et al. The role of glutamine in maintaining a healthy gut and supporting the metabolic response to injury and infection. J Surg Res. 1990; 48(4): 383-91.

4. Lacey JM, Wilmore DW. Is glutamine a conditionally essential amino acid? Nutr Rev. 1990; 48(8): 297-309.

5. Aziz M, Choudhary TJ, Shafiq M, Qureshi KH. Nutrition in surgical patients; role of partial parenteral nutritrition and total parenteral nutrition in immediate post operative period. Professional Med J. 2017; 24(3): 441-4.

6. Marik PE, Pinsky M. Death by parenteral nutrition. Intensive Care Med. 2003; 29(6): 867-9.

7. Weiman A, Adra J, Sablotzki A. Nutrition in the critically ill. Dtsch Med Wochenschr. 2011; 136(44): 2251-62.

8. Prado CM, Heymsfeld SB. Lean tissue imaging: a new era for nutritional assessment and intervention. J Parenter Enteral Nutr. 2014; 38(8): 940-53.

9. Reid CL, Campbell IT, Little RA. Muscle wasting and energy balance in critical illness. Clin Nutr. 2004; 23(2): 273-80.

10. Parry SM, El-Ansary D, Cartwright MS, Sarwal A, Berney S, Koopman R et al. Ultrasonography in the intensive care setting can be used to detect changes in the quality and quantity of muscle and is related to muscle strength and function. J Crit Care. 2015; 30(5): 1151.e9-e14.

11. Tonelli M, Klarenbach SW, Lloyd AM, James MT, Bello AK, Manns BJ, et al. Higher estimated glomerular filtration rates may be associated with increased risk of adverse outcomes, especially with concomitant proteinuria. Kidney international. 2011; 80(12): 1306-14.

12. Puthucheary ZA, Rawal J, McPhail M, Connolly B, Ratnayake G, Chan P et al. Acute skeletal muscle wasting in critical illness. JAMA. 2013; 310(15): 1591-600. među 1. i 7. dana $(p=0,006)$. U grupi $P$ gubitak mišićne mase $\mathrm{u}$ istom periodu nije bio statistički značajan. Obe grupe pokazale su statistički značajno smanjenje nivoa kreatinina u serumu od 1. do 3. ( $p=0,003$, $\mathrm{p}=0,03)$ i 1. i 7. $(\mathrm{p}=0,003)$ dana. Vrednosti razlika između 1. i 3. i 1. i 7. dana bile su 7,57 $\pm 4,12 \mathrm{mg} / \mathrm{dl}$ i $10,71 \pm 5,79 \mathrm{mg} / \mathrm{dl}$ u grupi E i $11,43 \pm 10,66 \mathrm{mg} / \mathrm{dl} \mathrm{i}$ $15,28 \pm 8,28 \mathrm{mg} / \mathrm{dl}$ u grupi P. Zaključak: U našoj studiji utvrdili smo značajno smanjenje mišićne mase procenjene ultrazvučnim merenjem m.quadriceps femoris - a kod pacijenata na enteralnoj ishrani nakon trećeg dana.

Ključne reči: kritično oboleli pacijenti, enteralna ili parenteralna ishrana, gubitak mišićne mase, ultrasonografija, koncentracija kreatinina u serumu.

13. Andrews R, Greenhaff P, Curtis S, Perry A, Cowley AJ. The effect of dietary creatine supplementation on skeletal muscle metabolism in congestive heart failure. Eur Heart J. 1998; 19(4): 617-22.

14. Thongprayoon C, Cheungpasitporn W, Akhoundi A, Ahmed AH, Kashani KB. Actual versus ideal body weight for acute kidney injury diagnosis and classifcation in critically ill patients. BMC Nephrol. 2014; 15: 176.

15. Schutte JE, Longhurst JC, Gaffney FA, Bastian BC, Blomqvist CG. Total plasma creatinine: an accurate measure of total striated muscle mass. J Appl Physiol Respir Environ Exerc Physiol. 1981; 51(3): 762-6.

16. Palmer C. Major trauma and the injury severity score-where should we set the bar. Annu Proc Assoc Adv Automot Med. 2007; 51: 13-29.

17. Morton RW, McGlory C, Phillips SM. Nutritional interventions to augment resistance training-induced skeletal muscle hypertrophy. Front Physiol. 2015; 6: 245.

18. Hoffer Lj, Bistrian BR: Appropriate protein provision in critical illness: a systematic and narrative review. Am J Clin Nutr. 2012; 96(3): 591-600.

19. Alberda C, Gramlich L, Jones N, Jeejeebhoy K, Day AG, Dhaliwal R, et al. The relationship between nutritional intake and clinical outcomes in critically ill patients: Results of an international multicenter observational study. Intensive Care Med. 2009; 35(10): 1728-37.

20. Heyland DK, Schroter-Noppe D, Drover JW, Jain M, Keefe L, Dhaliwal R, et al. Nutrition support in the critical care setting: Current practice in Canadian ICUs - Opportunities for improvement?. JPEN J Parenter Enteral Nutr. 2003; 27(1): 74-83.

21. RiceTW, Swope T, Bozeman S, Wheeler AP. Variation in enteral nutrition delivery in mechanically ventilated patients. Nutrition. 2005; 21(7-8): 786-92.

22. Stapleton RD, Jones N, Heyland DK. Feeding critically ill patients: What is the optimal amount of energy? Crit Care Med. 2007; 35(9 suppl): S535-40.

23. Bellomo R, Cass A, Cole L, Finfer S, Gallagher M, Lee $\mathrm{J}$, et al. Calorie intake and patient outcomes in severe acute kidney injury: Findings from the Randomized Evaluation of Normal vs. Augmented Level of Replacement Therapy (RENAL) study trial. Crit Care. 2014; 18(2): R45.

24. Weijs PJ, Looijaard WG, Beishuizen A, Girbes AR, Oudemans-van Straaten HM. Early high protein intake is asso- 
ciated with low mortality and energy overfeeding with high mortality in non-septic mechanically ventilated critically ill patients. Crit Care. 2014; 18(6): 701.

25. Artinian V, Krayem H, DiGiovine B. Effects of early enteral feeding on the outcome of critically ill mechanically ventilated medical patients. Chest. 2006; 129(4): 960-7.

26. Harvey SE, Parrott F, Harrison DA, Bear DE, Segaran $\mathrm{E}$, Beale R, Bellingan $\mathrm{G}$ et al. Trial of the route of early nutritional support in critically ill adults.. N Engl J Med. 2014; 371(18): 1673-84.

27. Puthucheary ZA, Rawal J, McPhail M, Connolly B, Ratnayake G, Chan P et al. Acute skeletal muscle wasting in critical illness. JAMA. 2013; 310(15): 1591-600.

28. Ferrie S, Allman-Farinelli M, Daley M, Smith K. Protein requirements in the critically ill: a randomised controlled trial using parenteral nutrition. JPEN J Parenter Enteral Nutr. 2016; 40(6): 795-805.

29. Casaer M, Mesotten D, Hermans G, Wouters R, Schetz M, Meyfroidt G et al. Early versus late parenteral nutrition in critically Ill adults. N Engl J Med 2011; 365(6): 506-17.

30. Hermans G, Casaer MP, Clerckx B, Güiza F, Vanhullebusch T, Derde S, et al. Effect of tolerating macronutrient deficit on the development of intensive-care unit acquired weakness: A subanalysis of the EPaNIC trial. Lancet Respir Med. 2013; 1(8): 621-9.

31. Doig GS, Simpson F, Sweetman EA, Finfer SR, Cooper DJ, Heighes PT, et al. Early parenteral nutrition in critically ill patients with short-term relative contraindications to early enteral nutrition: A randomized controlled trial. JAMA. 2013; 309(20): 2130-8.

32. Preiser C, van Zanten AR, Berger MM, Biolo G, Casaer MP, Doig GS, et al. Metabolic and nutritional support of critically ill patients: Consensus and controversies. Crit Care. 2015; 19: 35.

33. Dellinger P, Levy MM, Rhodes A, Annane D, Gerlach H, Opal SM, Sevransky JE et al. Surviving sepsis campaign gui- delines committee including The pediatric subgroup, surviving sepsis campaign: International guidelines for management of severe sepsis and septic shock, 2012.Intensive Care Med. 2013; 39(2): 165-228.

34. Manning EM, Shenkin A. Nutritional assessment in the critically ill. Crit Care Clin. 1995; 11(3): 603-34.

35. Chi-Fishman G, Hicks JE, Cintas HM, Sonies BC, Gerber LH. Ultrasound imaging distinguishes between normal and weak muscle. Arch Phys Med Rehabil. 2004; 85(6): 980-6.

36. Bleakney R, Maffulli N. Ultrasound changes to intramuscular architecture of the quadriceps following intramedullary nailing. J Sports Med Phys Fitness. 2002; 42(1): 120-5.

37. Uremovic M, Pasic MB, Seric V, Solter VV, Budic R, Bosnjak B, et al. Ultrasound measurement of the volume of musculus quadriceps after knee joint injury. Coll Antropol. 2004; 28 (Suppl 2): 227-33.

38. Abe T, Kawakami Y, Suzuki Y, Gunji A, Fukunaga T. Effects of 20 days bed rest on muscle morphology. J Gravit Physiol. 1997; 4(1): S10-4.

39. Ellis S, Kirby LC, Greenleaf JE. Lower extremity muscle thickness during 30-day 6 degrees head-down bed rest with isotonic and isokinetic exercise training. Aviat Space Environ Med. 1993; 64(11): 1011-5.

40. Ohata K, Tsuboyama T, Ichihashi N, Minami S. Measurement of muscle thickness as quantitative muscle evaluation for adults with severe cerebral palsy. Phys Ther. 2006; 86(9): 1231-9.

41. Akima H, Kawakami Y, Kubo K, Sekiguchi C, Ohshima H, Miyamoto A, et al. Effect of short-duration spaceflight on thigh and leg muscle volume. Med Sci Sports Exerc. 2000; 32(10): 1743-7.

42. Park J, Mehrotra R, Rhee CM, Molnar MZ, Lukowsky LR, Patel SS et al. Serum creatinine level, a surrogate of muscle mass, predicts mortality in peritoneal dialysis patients. Nephrol Dial Transplant. 2013; 28(8): 2146-55.

\section{Correspondence to/Autor za korespondenciju}

Biljana Andonovska

Tel: ++38970212880

St. Jurij Gagarin 6 No 12-1/10 Skopje, 1000, Macedonia

Email: andonovska.biljana1@gmail.com 